\title{
Botryosphaeriaceae from palms in Thailand II - two new species of Neodeightonia, $N$. rattanica and $N$. rattanicola from Calamus (rattan palm)
}

\section{Sirinapa Konta ${ }^{1}$, Sinang Hongsanan ${ }^{1}$, Alan J.L. Phillips ${ }^{3}$, E.B.G. Jones ${ }^{4}$, Saranyaphat Boonmee $^{1}$ \& Kevin D. Hyde ${ }^{1,2,4 *}$}

\author{
${ }^{1}$ Center of Excellence in Fungal Research, Mae Fah Luang University, Chiang Rai 57100, Thailand \\ ${ }^{2}$ Key Laboratory for Plant Biodiversity and Biogeography of East Asia, Kunming Institute of Botany, Chinese Academy \\ of Science, Kunming 650201, Yunnan, China \\ ${ }^{3}$ University of Lisbon, Faculty of Sciences, Biosystems and Integrative Sciences Institute (BioISI), Campo Grande, \\ 1749-016 Lisbon, Portugal \\ ${ }^{4}$ Department of Botany and Microbiology, College of Science, King Saud University, P.O. Box: 2455, Riyadh 1145, \\ Saudi Arabia
}

Konta S, Hongsanan S, Phillips AJL, Jones EBG, Boonmee S, Hyde KD 2016 Botryosphaeriaceae from palms in Thailand II - two new species of Neodeightonia, $N$. rattanica and $N$. rattanicola from Calamus (rattan palm). Mycosphere 7(7), 950-961, Doi 10.5943/mycosphere/si/1b/6

\begin{abstract}
A large number of ascomycetes have been described from the palm Calamus. In this study, we report on Neodeightonia species (Botryosphaeriaceae) from the rachides of Calamus spp. collected in Phang-Nga Province, Thailand. Morphological characters were studied and with support from phylogenetic analyses of combined ITS, LSU, SSU and TEF1- $\alpha$ sequence data we introduce two new species Neodeightonia rattanica, and $N$ rattanicola The new species are introduced with descriptions and illustrations and compared with other Neodeightonia species.
\end{abstract}

Key words - ascomycetes - Dothideomycetes - hyaline ascospores - palm fungi

\section{Introduction}

Rattan palms of the genus Calamus (Arecaceae) have been shown to be a rich source of unique fungal biodiversity, especially ascomycetes (Fröhlich \& Hyde 2000, Hyde et al. 2000). This paper is the second in a series on Botryosphaeriaceae from palms in Thailand. In the first in this series we introduced the new species Barriopsis archontophoenicis from Archontophoenix alexandrae (Konta et al. 2016). Botryosphaeriaceae species are common plant pathogens (Hanlin 1990), as well as saprobes, and occur on a wide range of host plants (Phillips et al. 2008). Phillips et al. (2008) introduced Neodeightonia phoenicum on Phoenix sp. in Spain. Subsequently, Ligoxigakis et al. (2013) provided a first report of palm rot disease caused by $N$. phoenicum on Phoenix sp. in Greece. Several Botryosphaeriales species have been found on palms (Hyde et al. 2007, Liu et al. 2010).

Recent treatments of Botryosphaeriaceae are those of Liu et al. (2012) who recognized 29 genera and Phillips et al. (2013) who accepted 17 genera and 110 species based on species known from culture. Botryosphaeriaceae species are common on a wide range of gymnosperms and 
angiosperms. Neodeightonia was established by Booth in Punithalingam (1969), with the type species Neodeightonia subglobosa (Punithalingam 1969). In their broad concept of Botryosphaeria von Arx and Muller (1975), in which they considered that ascospores can be brown, transferred the type species, N. subglobosa, to Botryosphaeria. However, Phillips et al. $(2008,2013)$ and Liu et al. (2012) accepted Neodeightonia as a distinct genus based on its dark, 1-septate ascospores and this was supported by phylogenetic analyses. Dai et al. (2016) introduced N. microspora D.Q. Dai \& K.D. Hyde and recollected N. subglobosa.

In this paper, we introduce two new Neodeightonia species from the rachides of Calamus. They are morphologically unique and are supported by DNA sequence analyses. The two new species are compared with other Neodeightonia species.

\section{Materials \& Methods}

\section{Collection, isolation and identification}

Rachises of Calamus were collected from Phang-Nga Province, Thailand. The specimens were examined following the methods described by Phukhamsakda et al. (2015), isolations were made from single ascospores following the method of Chomnunti et al. (2014) and sporulation in culture was achieved following the method of Phookamsak et al. (2015). Culture characteristics such as growth rate, colony shape, mycelium colour and morphology of the asexual morph were determined after incubation at $25^{\circ} \mathrm{C}$ in natural light/dark for up to 2 weeks.

The holotypes of the newly described Neodeightonia species were deposited in the herbarium of Mae Fah Luang University (MFLU), Chiang Rai, Thailand with isotypes in the Cryptogamic Herbarium, Kunming Institute of Botany, Academia Sinica (HAKS) and ex-type cultures are deposited in Mae Fah Luang Culture Collection (MFLUCC). Facesoffungi and Index Fungorum numbers were registered (Jayasiri et al. 2015, Index Fungorum 2016).

\section{Fungal DNA extraction and PCR reaction}

Genomic DNA was extracted from fresh mycelium grown on MEA for 2 weeks using the Biospin Fungus Genomic DNA Extraction Kit (BioFlux $\left.{ }^{\circledR}\right)$ (Phukhamsakda et al. 2015). The ITS region was amplified with primers ITS1 and ITS4 (White et al. 1990), the LSU region with LROR and LR5 (Vilgalys \& Hester 1990), the SSU with NS1 and NS4 (White et al. 1990), and the TEF1$\alpha$ gene with EF1-728F and EF1-986R (Carbone \& Kohn 1999). The PCR products were checked on $1 \%$ agarose electrophoresis gels stained with ethidium bromide. The purified PCR products were sequenced by Shangkai Majorbio Biopharm Technology Co., Ltd, China.

\section{Sequence alignment and phylogenetic analyses}

DNA sequences were checked with BioEdit (Hall 1999) and MEGA6 (Tamura et al. 2013). A BLAST search with the ITS sequences was used to reveal the closest matching taxa in Botryosphaeriaceae (Liu et al. 2014, Phookamsak et al. 2015). Multiple sequence alignments were done with MAFFT (Katoh et al. 2013) online alignment (http://www.ebi.ac.uk/Tools/msa/mafft/, Li et al. 2015). ITS, LSU, SSU, and TEF1- $\alpha$ sequences datasets were first analyzed separately and then the individual datasets were concatenated into a combined dataset and prepared in MEGA6 (Tamura et al. 2013). Data were converted from fasta to nexus format with Clustal X (Thompson et al. 1997). Maximum parsimony (MP) analysis was done with PAUP v. $4.0 b 10$ (Swofford 2002) and robustness of the branches was determined with 1000 bootstrap replicates along with max-trees set at 1000. The models of evolution were determined with MrModeltest 2.2 (Nylander 2004) under the Akaike information criterion (AIC). The models selected were HKY+I, HKY+I+G, GTR+I, and $\mathrm{HKY}+\mathrm{G}$ for SSU, ITS, LSU and TEF1- $\alpha$ respectively, and GTR-GAMMA for the combined dataset (Nylander 2004). Maximum likelihood analysis was performed by RAxML GUI v.0.9b2 with 1000 bootstrap replicates (Silvestro \& Michalak 2010). The number of replications was inferred using the stopping criterion. Bootstrap values greater than $60 \%$ were accepted. Four chains 
Table 1 GenBank Accession numbers of the sequences used in phylogenetic analyses. New sequences are in bold.

\begin{tabular}{|c|c|c|c|c|c|}
\hline \multirow{2}{*}{ Species name } & \multirow{2}{*}{ Strain } & \multicolumn{4}{|c|}{ GenBank accession number } \\
\hline & & ITS & LSU & SSU & TEF \\
\hline Diplodia mutila & CBS 112553 & AY259093 & AY928049 & EU673213 & AY573219 \\
\hline Diplodia mutila & CBS 230.30 & DQ458886 & EU673265 & EU673214 & DQ458869 \\
\hline Diplodia seriata & CBS 112555 & AY259094 & AY928050 & KF766244 & AY573220 \\
\hline Diplodia seriata & CBS 119049 & DQ458889 & EU673266 & EU673216 & DQ458874 \\
\hline Lasiodiplodia gonubiensis & CMW14077 & AY639595 & - & - & DQ103566 \\
\hline Lasiodiplodia gonubiensis & CMW14078 & AY639594 & - & - & DQ103567 \\
\hline Lasiodiplodia margaritacea & CBS122519 & EU144050 & - & - & EU144065 \\
\hline Lasiodiplodia margaritacea & CBS122065 & EU144051 & - & - & EU144066 \\
\hline $\begin{array}{l}\text { Lasiodiplodia } \\
\text { pseudotheobromae }\end{array}$ & CBS116459 & EF622077 & EU673256 & KF766279 & EF622057 \\
\hline $\begin{array}{l}\text { Lasiodiplodia } \\
\text { pseudotheobromae }\end{array}$ & CBS447.62 & EF622081 & EU673255 & EU673198 & EF622060 \\
\hline Lasiodiplodia theobromae & CBS 164.96 & AY640255 & EU673253 & EU673196 & AY640258 \\
\hline Lasiodiplodia theobromae & CBS124.13 & DQ458890 & AY928054 & EU673195 & DQ458875 \\
\hline Neodeightonia microspora & MFLUCC 11-0483 & KU940110 & KU863099 & - & - \\
\hline Neodeightonia microspora & MFLUCC 11-0504 & KU940111 & KU863100 & - & - \\
\hline Neodeightonia palmicola & MFLUCC 10-0822 & HQ199221 & HQ199222 & HQ199223 & - \\
\hline Neodeightonia palmicola & MFLUCC10-0823 & HQ199224 & HQ199225 & HQ199226 & - \\
\hline Neodeightonia phoenicum & CBS 122528 & KF766198 & EU673261 & KF766285 & EU673309 \\
\hline Neodeightonia phoenicum & CBS 123168 & EU673339 & EU673260 & EU673204 & EU673308 \\
\hline Neodeightonia phoenicum & CBS 169.34 & EU673338 & EU673259 & EU673203 & EU673307 \\
\hline Neodeightonia rattanica & MFLUCC 15-0712 & KX646357 & KX646352 & KX646355 & KX646360 \\
\hline Neodeightonia rattanica & MFLUCC 15-0313 & KX646358 & KX646353 & - & KX646361 \\
\hline Neodeightonia rattanicola & MFLUCC 15-0319 & KX646359 & KX646354 & KX646358 & KX646362 \\
\hline Neodeightonia subglobosa & CBS 448.91 & KF766199 & DQ377866 & KF766286 & EU673306 \\
\hline Sphaeropsis visci & CBS 186.97 & EU673325 & EU754216 & EU754117 & EU673293 \\
\hline Sphaeropsis visci & CBS 100163 & EU673324 & EU754215 & EU754116 & EU673292 \\
\hline
\end{tabular}

Abbreviation: CBS: Centraalbureau voor Schimmelcultures, The Netherlands; CPC: Collection of Pedro Crous housed at CBS; IRAN: Iranian Fungal Culture Collection, Iranian Research Institute of Plant Protection, Iran; MFLUCC: Mae Fah Luang University Culture Collection, Chiang Rai, Thailand; MUCC: Culture Collection, Laboratory of Plant Pathology, Mie University, Tsu, Mie prefecture, Japan; IMI: CABI Bioscience, Egham, UK; CMW: M.J. Wingfield, FABI, University of Pretoria, South Africa; ICMP: International Collection of Micro-organisms from Plants, Landcare Research, New Zealand; STE-U: Culture collection of the Department of Plant Pathology, University of Stellenbosch, South Africa.

were run for the individual and combined data sets. Posterior probabilities (PP) (Rannala \& Yang 1996, Zhaxybayeva \& Gogarten 2002) were determined by Markov Chain Monte Carlo sampling (MCMC) using MrBayes v3.1.2 (Huelsenbeck \& Ronquist 2001). Five million generations was run with a sampling frequency of every 100 generations. The first 5,000 trees were excluded as burn-in phase. Bayesian posterior probabilities (BYPP) were calculated from the remaining 45,000 trees and values greater than 0.95 were accepted. The phylogenetic tree was visualized with Tree View32 (Page 1996). Trees and alignment files were deposited in TreeBase (submission ID: 19661).

\section{Result}

\section{Phylogenetic analyses}

The sequence alignment comprised 24 taxa of representative strains of Botryosphaeriaceae, including our new taxa. Sphaeropsis visci was used as outgroup. Phylogenetic trees were generated by maximum parsimony (MP), maximum likelihood (ML) and Bayesian analyses of combined ITS, LSU, SSU and TEF1- $\alpha$ sequence data. Topology of the trees produced by these three methods was similar and the best scoring ML tree is shown in Fig. 1. The new species Neodeightonia rattanica, 


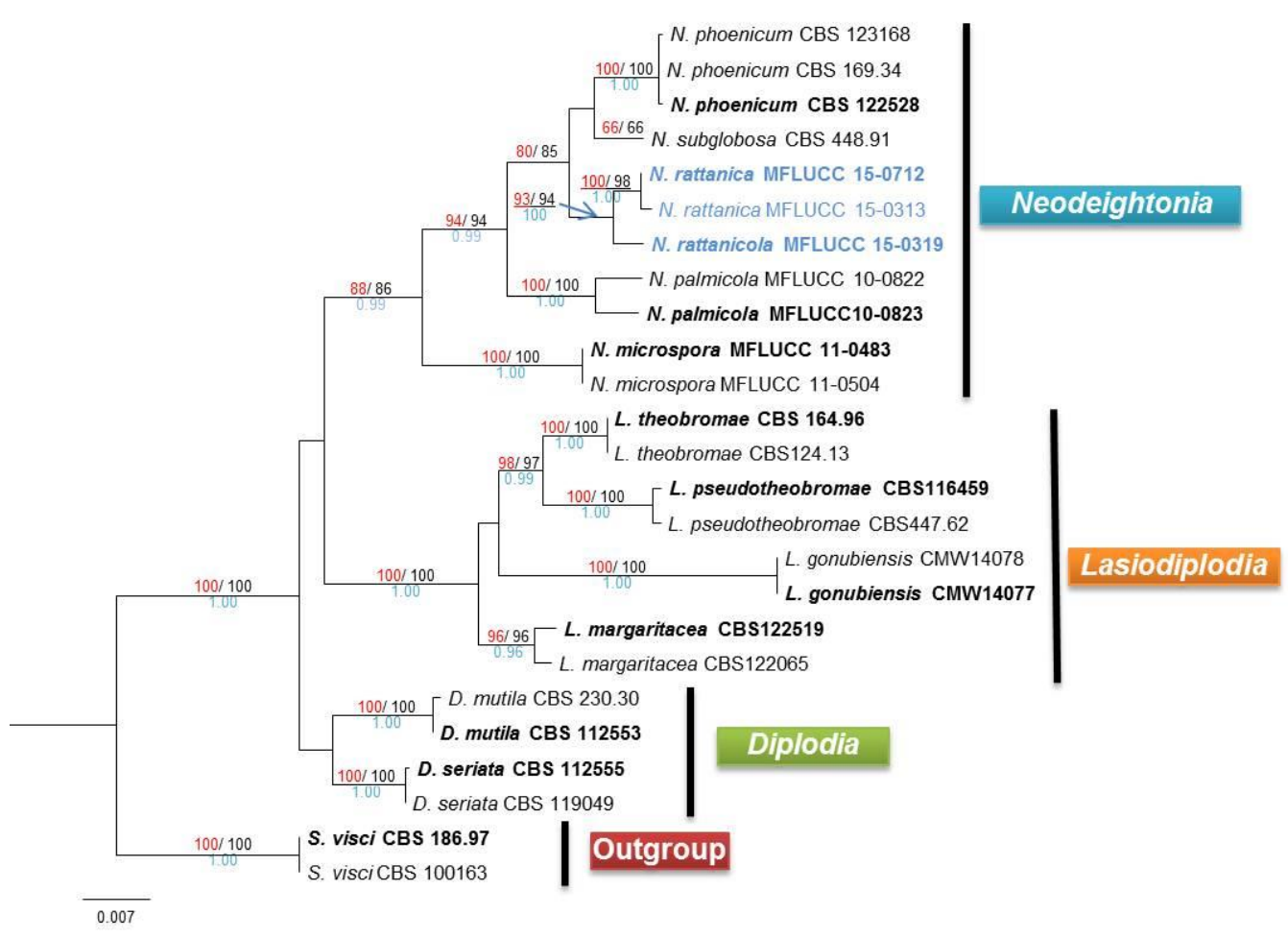

Fig. 1 - Maximum likelihood (ML) tree derived from analysis of a combined ITS, LSU, SSU, and TEF1- $\alpha$ sequence dataset. Bootstrap support values for maximum parsimony (MP, black) and maximum likelihood (ML, red) greater than $60 \%$ and Bayesian posterior probabilities (BYPP, blue) greater than 0.95 are given at the nodes. The tree is rooted to Sphaeropsis visci. Strain numbers are mentioned after the species names. The new species are highlighted in blue. Ex-type strains are in bold.

and $N$. rattanicola cluster with high bootstrap support (93\% ML, 94\% MP, $1.00 \mathrm{PP}$ ) within the Neodeightonia clade, which forms a sister clade to Lasiodiplodia. Neodeightonia rattanica and $N$. rattanicola are closely related but the two species are separated by 9 bp differences in ITS, and 5 bp differences in LSU.

\section{Taxonomy}

Neodeightonia rattanica Konta \& K.D. Hyde, sp. nov.

Figs 2-3

Index Fungorum number: IF552168; Facesoffungi number: FoF 02237

Etymology: The specific epithet refers to the common name for the host, rattan.

Holotype: MFLU: 15-1443

Saprobic on rachis of Calamus sp. Sexual morph: Ascomata 222-241 high $\times 246-278 \mu \mathrm{m}$ diam. $(\overline{\mathrm{x}}=262 \times 235 \mu \mathrm{m}, \mathrm{n}=10)$, immersed, solitary, scattered, uniloculate, subglobose, brown to reddish brown, with a long neck, rounded at the base. Ostiole central non-papillate. Peridium 49-76 $\mu m$ diam. $(\overline{\mathrm{x}}=72 \mu m, \mathrm{n}=10)$, relatively thick, comprising several layers, outer layer thick, comprising reddish brown-walled cells of textura angularis, inner layer thin, comprising hyaline cells of textura angularis. Hamathecium comprising hypha-like, hyaline, septate, cellular pseudoparaphyses, up to $2.7 \mu \mathrm{m}$ wide, often constricted at the septa. Asci 113-141 $\times 19-25 \mu \mathrm{m}(\overline{\mathrm{x}}=$ $138 \times 22 \mu m, \mathrm{n}=10$ ), 8-spored, bitunicate, fissitunicate, cylindrical-clavate, with a thick endotunica, long pedicellate, apically thickened, with a distinct, ocular chamber. Ascospores 22-25 $\times 8-11 \mu m(\overline{\mathrm{x}}=23 \times 10 \mu m, \mathrm{n}=20)$, overlapping biseriate or obliquely biseriate, hyaline, ellipsoidal-fusiform, aseptate, often with a large guttule at the centre when immature, becoming granulate, with terminal apiculi, smooth-walled, surrounded by thick mucilaginous sheath. Asexual morph: Coelomycetous. Conidiomata stromatic 245-349 high $\times 208-305 \mu \mathrm{m}$ diam. $(\overline{\mathrm{x}}=297 \times 255$ 
$\mu m, \mathrm{n}=5$ ), pycnidial, superficial, purplish to black, covered with dense mycelium, on PDA uni-to multilocular, individual or aggregated. Paraphyses cylindrical, aseptate, hyaline. Conidiogenous cells 6-11 $\times 2-3 \mu m(\overline{\mathrm{x}}=9.7 \times 2.7 \mu m, \mathrm{n}=10)$, holoblastic, cylindrical to subcylindrical, hyaline. Conidia 19-22 × 7-9 $\mu \mathrm{m}(\overline{\mathrm{x}}=20.7 \times 8.4 \mu \mathrm{m}, \mathrm{n}=20)$, initially hyaline, pale to dark brown when mature, unicellular, ellipsoid to obovoid, thick-walled, with granular content, rounded at the apex.

Culture characters - Ascospores germinating on MEA within 24 hours and germ tubes produced from both ends. Colonies on MEA fast growing, after 2 weeks reaching 7-8.5 cm diam. at $25^{\circ} \mathrm{C}$, white at the edge, grey in the middle, outwardly strongly radiating. After 5 months of incubation, the colonies on MEA, becoming grey-olivaceous and spongy, hyphae, septate, branched and smooth, form asexual morph after 2 months.

Material examined - THAILAND, Phang-Nga, on dead rachis of Calamus sp. (Arecaceae), 6 December 2014, S. Konta, DNH05e (MFLU 15-1443, holotype; MFLU 15-0288, HKAS92531, HKAS92529, isotype); ex-type living culture, MFLUCC 15-0712, MFLUCC 15-0313.

Notes - Neodeightonia rattanica is characterized by large ascomata and ellipsoidalfusiform, granulate ascospores, often with a single large guttule in immature ascospores, with polar apiculi and a thick mucilaginous sheath. Multi-locus analyses showed that $N$. rattanica (strain MFLUCC 15-0712) is closely related to N. rattanicola (strain MFLUCC 15-0319), but forms a distinct lineage (Fig. 1). Morphologically, Neodeightonia rattanica differs from N. rattanicola in having larger ascomata with a reddish brown peridium, while in $N$. rattanicola the peridium is dark brown to black (Figs. 2 vs Fig. 4, Table 2). The conidiomata of $N$. rattanica produced on media are purplish to black, while in $N$. rattanicola conidiomata on media are larger and dark brown to reddish brown (Figs. 3 vs Fig. 5, Table 3). Neodeightonia rattanica differs from N. subglobosa (the type species) in having hyaline, aseptate, granulate ascospores, often with a single large guttule in immature ascospores, while $N$. subglobosa has brown, 1-septate ascospores. Neodeightonia rattanica has ellipsoidal-fusiform ascospores with polar apiculi, while $N$. microspora has obovoid ascospores without polar apiculi (Figs 2 viz Fig $2 \mathrm{f}-\mathrm{j}$ Dai et al. (2016), Table 2). Although it is similar to $N$. palmicola in the sexual morph they differ in the asexual morph with aseptate conidia while conidia of $N$. palmicola have a single septum.

Neodeightonia rattanicola Konta \& K.D. Hyde, sp. nov.

Figs 4-5 Index Fungorum number: IF552169; Facesoffungi number: FoF 02238

Etymology: The specific epithet refers to the common name of host (rattan) and the Latin cola meaning loving.

Holotype: MFLU: 15-0294

Saprobic on rachis of Calamus sp., Sexual morph: Ascomata 180-215 high $\times 146-168 \mu m$ diam. $(\overline{\mathrm{x}}$ $=197 \times 155 \mu m, \mathrm{n}=10$ ), immersed to semi-immersed, solitary, scattered, uniloculate, subglobose to irregular, dark brown or black, with a long neck, irregular at the base. Ostiole central nonpapillate. Peridium 35-51 $\mu \mathrm{m}$ diam. $(\overline{\mathrm{x}}=45 \mu \mathrm{m}, \mathrm{n}=10)$, comprising several layers, outer layer thick, comprising dark brown to black-walled cells of textura angularis, inner layer thin, comprising hyaline cells of textura angularis. Hamathecium comprising hypha-like, hyaline, septate, cellular pseudoparaphyses, up to $3.27 \mu \mathrm{m}$ wide, often constricted at the septa. Asci 91-108 $\times 19-25 \mu m(\overline{\mathrm{x}}=101 \times 22 \mu m, \mathrm{n}=10), 8$-spored, bitunicate, fissitunicate, cylindrical-clavate, with thick endotunica, long pedicellate, apically thickened, with a distinct, ocular chamber. Ascospores $22-26 \times 8-11 \mu m(\overline{\mathrm{x}}=23 \times 10 \mu m, \mathrm{n}=20)$, overlapping biseriate or obliquely $2-3$-seriate, hyaline, ellipsoidal-fusiform, aseptate, with polar apiculi, smooth-walled, surrounded by thin mucilaginous sheath. Asexual morph: Coelomycetous. Conidiomata stromatic 420-510 high $\times 357-443 \mu \mathrm{m}$ diam. $(\overline{\mathrm{x}}=446 \times 381 \mu \mathrm{m}, \mathrm{n}=5)$, pycnidial, superficial, dark brown to black, covered with dense mycelium, on PDA mostly uniloculate, individual or aggregated. Paraphyses cylindrical, aseptate hyaline. Conidiogenous cell 4.4-12.5 $\times 1.5-4.3 \mu \mathrm{m}(\overline{\mathrm{x}}=9.4 \times 3.4 \mu \mathrm{m}, \mathrm{n}=10)$, holoblastic, cylindrical to subcylindrical, hyaline. Conidia $13-20 \times 7-8 \mu m(\overline{\mathrm{x}}=17.3 \times 8 \mu \mathrm{m}, \mathrm{n}=20)$, initially hyaline, pale to dark brown when mature, unicellular, ellipsoid to obovoid, thick-walled, granulate, rounded at apex. 

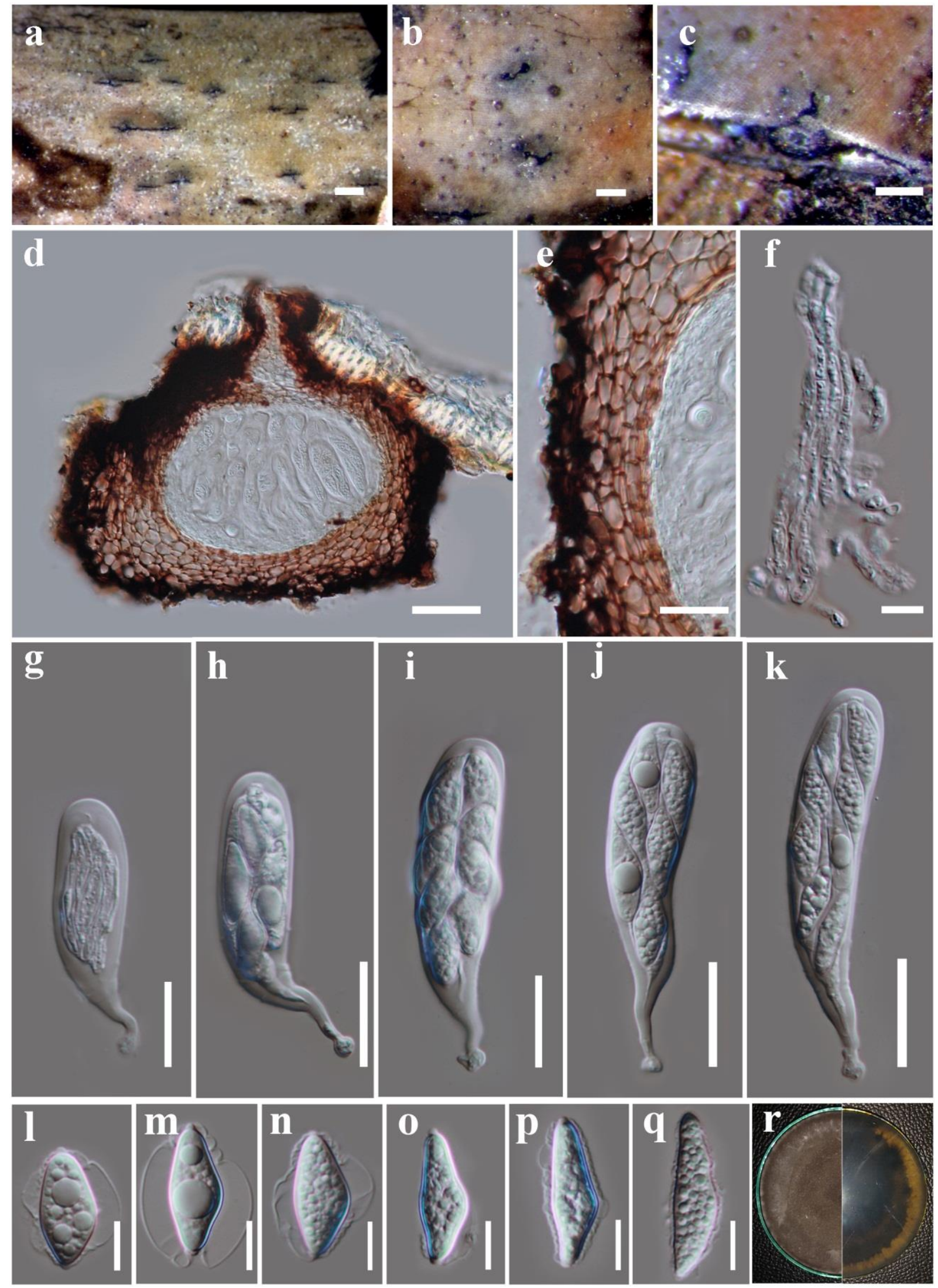

$\mathbf{k}$
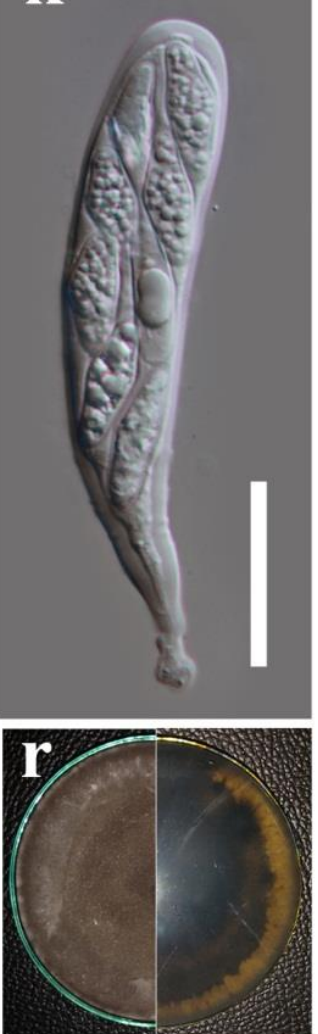

Fig. 2 - Neodeightonia rattanica (holotype) a. Appearance of ascomata on host substrate. b, c. Close-up of ascomata. d. Section of ascoma. e. Peridium. f. Pseudoparaphyses. g-k. Immature to mature asci. j, m. Ascospores with a single large guttule. $1-\mathrm{q}$. Ascospores with polar apiculi and mucous sheath. r. Culture on MEA after 1. month, front and reverse. Scale bars: $\mathrm{a}=500 \mu \mathrm{m}, \mathrm{b}-\mathrm{c}=$ $200 \mu m, \mathrm{~d}=50 \mu m, \mathrm{e}=20 \mu m, \mathrm{f}=10 \mu m, \mathrm{~g}-\mathrm{k}=20 \mu m, \mathrm{l}-\mathrm{q}=10 \mu m$. 


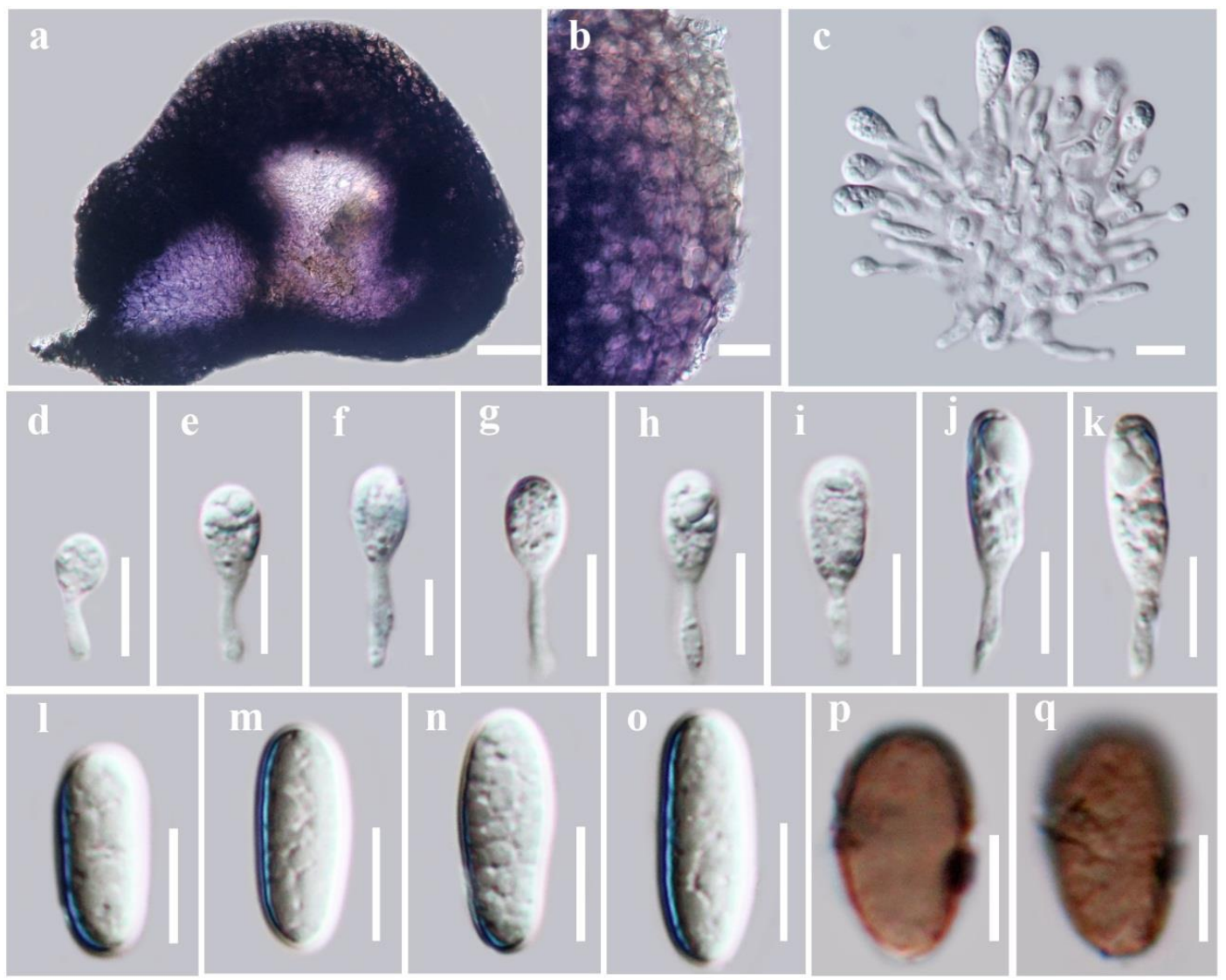

Fig. 3 - Neodeightonia rattanica (from ex-type culture) a. Section of conidioma. b. Peridium. c-k. Conidiogenous cells with conidia. $1-0$. Immature conidia. $\mathrm{p}-\mathrm{q}$. Mature conidia. Scale bars: $\mathrm{a}=50$ $\mu m, \mathrm{~b}-\mathrm{q}=10 \mu m$.

Culture characters - Ascospores germinating on MEA within 24 hours and germ tube produced from cell. Colonies on MEA fast growing, after 2 weeks reaching $8-9 \mathrm{~cm}$ diam. at $25^{\circ} \mathrm{C}$, white at the edge, grey in the middle and outwardly strongly radiating. After 1 month of incubation, the colonies on MEA, grey-olivaceous and spongy, hyphae, septate, branched and smooth, form asexual morph after 6 weeks.

Material examined - THAILAND, Phang-Nga, on dead rachis of Calamus sp. (Arecaceae), 6 December 2014, S. Konta, DNH02p, (MFLU 15-0294, holotype; HKAS92530, isotype); ex-type living culture, MFLUCC 15-0319.

Notes - The phylogenetic analyses indicated that Neodeightonia rattanicola (strain MFLUCC 15-0319) is closely related to $N$. rattanica (strain MFLUCC 15-0712) but they are distinct species (Fig. 1). Morphological differences are discussed under the latter species. Neodeightonia rattanicola differs from $N$. subglobosa in having hyaline, aseptate ascospores, while $N$. subglobosa has brown, 1-septate ascospores. Neodeightonia rattanicola is distinct from $N$. microspora in having ellipsoidal-fusiform ascospores with polar apiculi, while $N$. microspora has obovoid ascospores lacking polar apiculi (Table 2) and it differs from N. palmicola and $N$. phoenicum in having aseptate conidia while N. palmicola and N. phoenicum have 1-septate conidia.

\section{Discussion}

In this study, we introduce two new species, viz. Neodeightonia rattanica and $N$. rattanicola. These two species were found on rattan palms and were differentiated from all other known species based on morphology and phylogenetic analyses. Phylogenetically N. rattanica and $N$. rattanicola cluster together with $N$. subglobosa and $N$. phoenicum, but form distinct lineages. Neodeightonia rattanica and $N$. rattanicola are morphologically similar to $N$. phoenicum but differ in having non-septate conidia, while $N$. phoenicum has 1-septate conidia. 

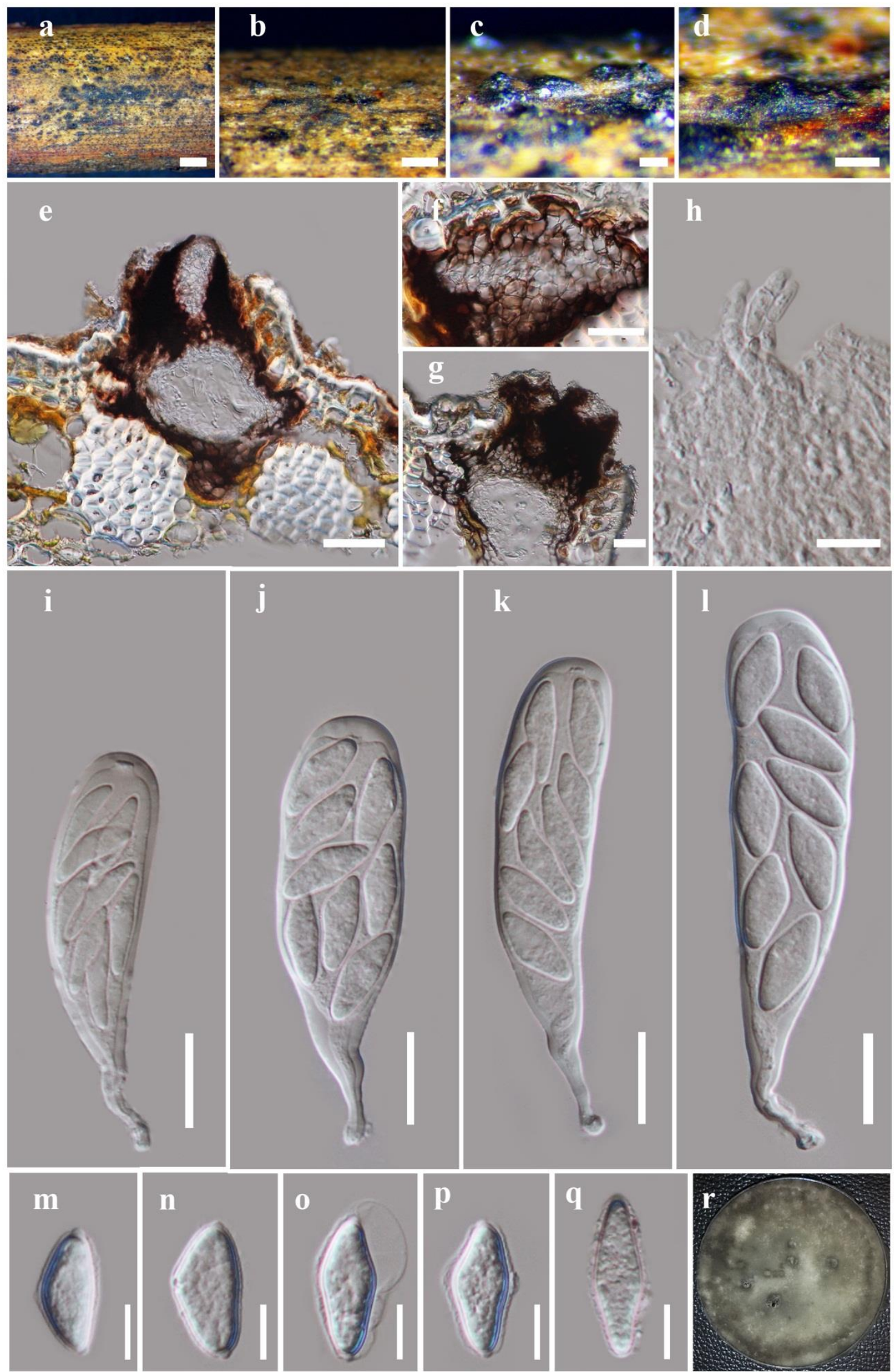

Fig. 4 - Neodeightonia rattanicola (MFLU 15-0294, holotype) a. Ascomata on host substrate. b-d. Close-up of ascomata. e. Section of ascoma. f. Peridium. g. Neck. h. Pseudoparaphyses. i-l. Asci. $\mathrm{m}-\mathrm{q}$. Ascospores. $\mathrm{r}$ Surface view of culture on MEA after 1 month. Scale bars: $\mathrm{a}=1,000 \mu \mathrm{m}, \mathrm{b}=$ $500 \mu m, \mathrm{c}-\mathrm{d}=200 \mu \mathrm{m}, \mathrm{e}=50 \mu \mathrm{m}, \mathrm{f}, \mathrm{h}=10 \mu \mathrm{m}, \mathrm{g}=20 \mu \mathrm{m}, \mathrm{i}-\mathrm{l}=20 \mu \mathrm{m}, \mathrm{m}-\mathrm{q}=10 \mu \mathrm{m}$. 

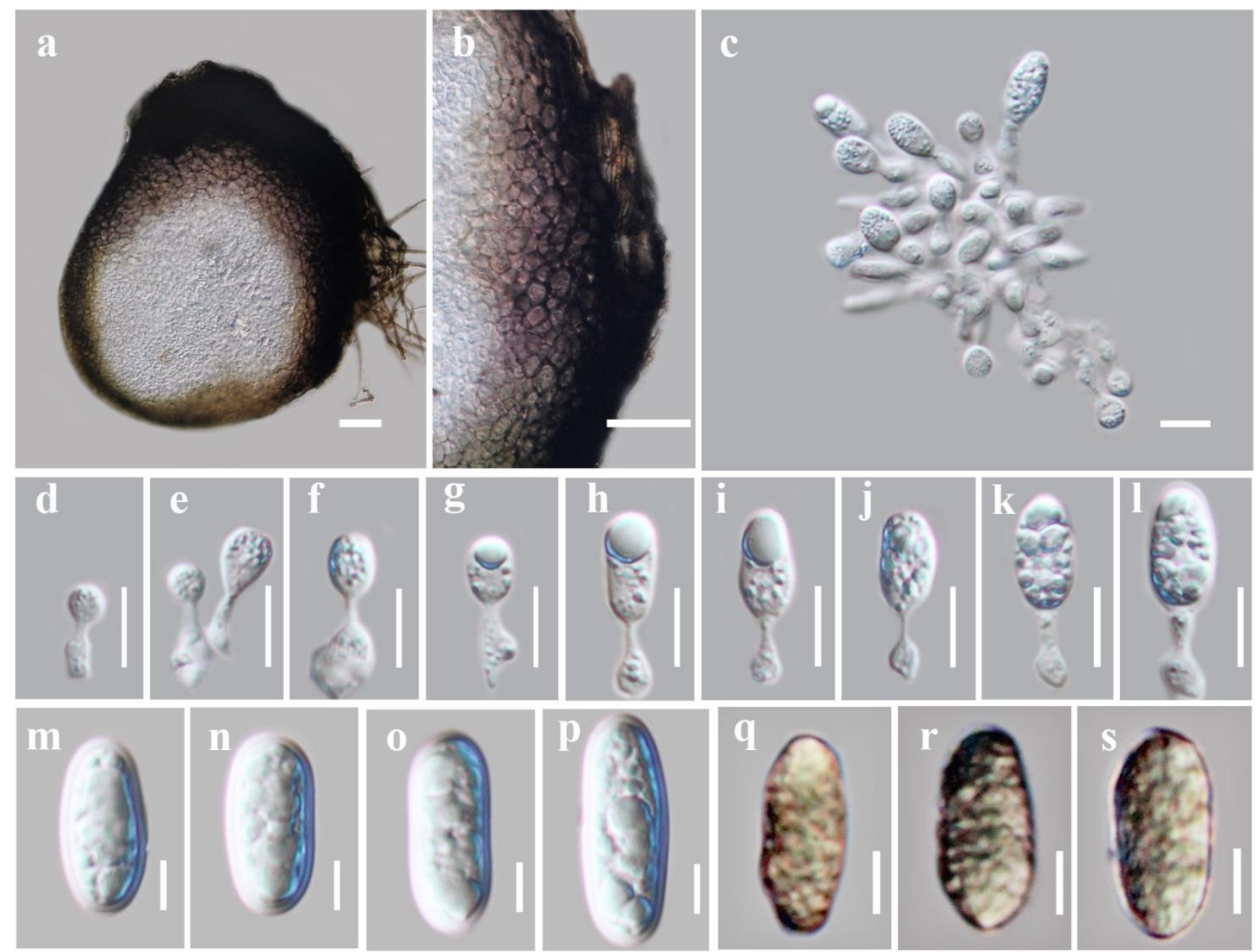

Fig. 5 - Neodeightonia rattanicola (MFLUCC 15-0319, holotype) a. Section of conidioma. b. Peridium. $\mathrm{c}-1$. Conidiogenous cells with conidia. $\mathrm{m}-\mathrm{p}$. Immature conidia. q-s. Mature conidia. Scale bars: $\mathrm{a}-\mathrm{b}=50 \mu \mathrm{m}, \mathrm{c}-\mathrm{l}=10 \mu \mathrm{m}, \mathrm{m}-\mathrm{s}=5 \mu \mathrm{m}$.

Neodeightonia species belong in the family Botryosphaeriaceae (Botryosphaeriales, Lui et al. 2014) and N. subglobosa is the type species (Punithalingam 1969). There are presently six accepted species (Phillips et al. 2008, Liu et al. 2010, Dai et al. 2016). The sexual morph of Neodeightonia is characterized by hyaline, aseptate ascospores, with polar apiculi and surrounded by a mucilaginous sheath. The asexual morph is characterized by conidia that are initially hyaline that may become brown and 1-septate at maturity, with smooth to finely roughened walls or with fine striations (Phillips et al. 2008, 2013, Liu et al. 2012, Dai et al. 2016). This feature is unique to Neodeightonia differentiating it from all other genera in the Botryosphaeriaceae.

Neodeightonia rattanica and $N$. rattanicola form the asexual morph in cultures after up to 6 weeks of incubation. Although the sexual morph of $N$. subglobosa (type species) has been reported in cultures (Punithalingam 1969) we are unable to find the sexual morph in any culture even after long periods of incubation. The type species of Neodeightonia was found on Bambusa while the other species listed in Index Fungorum (2016) have been found on palms, such as Arenga westerhoutii, Phoenix sp. and Caryota urens. The two species introduced in this paper were isolated from the rattan palm. Thus, this genus is probably specific in host substrate or tissue. Tissue-specificity has been suggested for saprobic microfungi on palms by Fröhlich \& Hyde (2000). Although Neodeightonia species have been reported associated with disease symptoms, pathogenicity has not been tested for any of them and thus it is not known if they are primary pathogens or secondary invaders of diseased hosts. 
Table 2 Sexual morph

\begin{tabular}{|c|c|c|c|c|c|}
\hline Species name & Ascomata & Peridium & Hamathecium & Ascospore & References \\
\hline $\begin{array}{l}\text { Neodeightonia rattanica } \\
\text { MFLU 15-1443 (Figs 2) }\end{array}$ & $222-241 \mu m$ high $\times 246-278 \mu m$ diam. & 49-76 $\mu m$ diam. & $2.7 \mu m$ diam. & $\begin{array}{l}22-25 \times 8-11 \mu m \\
(\bar{x}=23 \times 10 \mu m, n=20)\end{array}$ & This study \\
\hline $\begin{array}{l}\text { Neodeightonia rattanicola } \\
\text { MFLU 15-0294 (Figs 4) }\end{array}$ & $180-215 \mu m$ high $\times 146-168 \mu m$ diam. & 35-51 $\mu \mathrm{m}$ diam. & $3.2 \mu m$ diam. & $\begin{array}{l}22-26 \times 8-11 \mu m \\
(\bar{x}=23 \times 10 \mu m, \mathrm{n}=20),\end{array}$ & This study \\
\hline $\begin{array}{l}\text { Neodeightonia phoenicum A.J.L. } \\
\text { Phillips \& Crous }\end{array}$ & & & & Undetermined & Phillips et al. 2008 \\
\hline $\begin{array}{l}\text { Neodeightonia palmicola J.K. Liu, } \\
\text { Phook. \& K.D. Hyde }\end{array}$ & $\begin{array}{l}180-230 \mu \mathrm{m} \text { high (excluding the neck), } \\
270-420 \mu \mathrm{m} \text { diam. }\end{array}$ & $26-55 \mu m$ diam. & 3-5 $\mu m$ diam. & $\begin{array}{l}23-31.5 \times 8.5-12.5 \mu m \\
(\bar{x}=24 \times 10 \mu m, \mathrm{n}=20)\end{array}$ & Liu et al. 2010 \\
\hline $\begin{array}{l}\text { Neodeightonia microspora D.Q. } \\
\text { Dai \& K.D. Hyde }\end{array}$ & $100-150 \mu m$ high $\times 95-150 \mu m$ diam. & 15-20 $\mu \mathrm{m}$ diam. & absence & $10-12 \times 4.5-6 \mu \mathrm{m}$ & Dai et al. 2016 \\
\hline $\begin{array}{l}\text { Neodeightonia subglobosa C. } \\
\text { Booth (type species) }\end{array}$ & $160-220 \mu \mathrm{m}$ high $\times 250-370 \mu \mathrm{m}$ diam. & $17-40 \mu m$ diam. & $2-4 \mu m$ diam. & $17-21 \times 8-10.5 \mu m$ & $\begin{array}{l}\text { Phillips et al. 2008, Lui et } \\
\text { al. 2014, Dai et al. } 2016\end{array}$ \\
\hline
\end{tabular}

Table 3 Asexual morph

\begin{tabular}{|c|c|c|c|c|c|}
\hline Species name & Conidiomata & Conidiogenous cell & Conidia & Growth rate & References \\
\hline $\begin{array}{l}\text { Neodeightonia rattanica } \\
\text { MFLUCC 15-0396 (Figs } \\
\text { 3) }\end{array}$ & $\begin{array}{l}245-349 \text { high } \times 208- \\
305 \mu m \text { diam. }\end{array}$ & $6.1-11.2 \times 2.1-3.2 \mu \mathrm{m}$ & $19-22 \times 7-9 \mu m$ & $\begin{array}{l}\text { MEA fast growing, after } 2 \\
\text { weeks, } 7-8.5 \mathrm{~cm} \text { diam. at } 25^{\circ} \mathrm{C} .\end{array}$ & This study \\
\hline $\begin{array}{l}\text { Neodeightonia rattanicola } \\
\text { MFLUCC 15-0712 (Figs } \\
\text { 5) }\end{array}$ & $\begin{array}{l}420-510 \text { high } \times 357- \\
443 \mu m \text { diam. }\end{array}$ & $4.4-12.5 \times 1.5-4.3 \mu \mathrm{m}$ & $13-20 \times 7-8 \mu \mathrm{m}$ & $\begin{array}{l}\text { MEA fast growing, after } 2 \\
\text { weeks, } 7-8.5 \mathrm{~cm} \text { diam. at } 25^{\circ} \mathrm{C} \text {. }\end{array}$ & This study \\
\hline Neodeightonia phoenicum & & & $\begin{array}{l}(14.5-) 17-21(-24) \times(9- \\
) 10-12.5(-14) \mu m \\
-1 \text {-septate }\end{array}$ & & Phillips et al. 2008, 2013, \\
\hline Neodeightonia palmicola & & $9-20 \times 3-6 \mu m$ & $\begin{array}{l}17.5-24.5 \times 9.5-12.5 \\
\mu m \\
-1 \text {-septate }\end{array}$ & $\begin{array}{l}\text { PDA fast growing, after } 4 \text { days } \\
50 \mathrm{~mm} \text {. }\end{array}$ & Liu et al. 2010 \\
\hline $\begin{array}{l}\text { Neodeightonia subglobosa } \\
\text { (type species) }\end{array}$ & 150-200 $\mu m$ diam. & $5-12.5 \times 2-3 \mu m$ & $11-13.5 \times 8-10.5 \mu m$ & $\begin{array}{l}\text { After } 1 \text { week, } 5 \mathrm{~cm} \text { diam. at } 28 \\
{ }^{\circ} \mathrm{C}\end{array}$ & $\begin{array}{l}\text { Phillips et al. 2008, 2013, Lui et } \\
\text { al. 2015, Dai et al. } 2016\end{array}$ \\
\hline
\end{tabular}




\section{Acknowledgements}

Saranyaphat Boonmee would like to thank the National Research Council of Thailand (grant for microfungi on palms no. 2559A30702006) for supporting studies on microfungi on palms and the Mushroom Research Foundation for partly supporting this research. Sirinapa Konta is grateful to Wenjing Li, Ishani Goonasekara, Saithong Kaewchaii, Ausana Mapook, Saowaluck Tibpromma, Rungtiwa Phookamsak, Mingkwan Doilom, Chayanard Phukhamsakda, Benjarong Thongbai, Chada Norphunpuan, Boontiya Chuankid, and Shaun Pennycook for their valuable suggestions.

\section{References}

Carbone I, Kohn LM. 1999 - A method for designing primer sets for speciation studies in filamentous ascomycete. Mycologia 91, 553-556.

Chomnunti P, Hongsanan S, Hudson BA, Tian Q, Persoh D, Dhami MK, Alias AS, Xu J, Liu X, Stadler M, Hyde KD. 2014 - The sooty moulds. Fungal Diversity 66, 1-36.

Dai DQ, Phookamsak R, Wijayawardene NN, Li WJ, Bhat DJ, Xu JC, Taylor JE, Hyde KD, Chukeatirote E. 2016 - Bambusicolous fungi. Fungal Diversity, 1-105.

Fröhlich J, Hyde KD. 2000. - Palm microfungi. Fungal Diversity Research Series 3, 1-393.

Hall TA. 1999 - BioEdit: a user-friendly biological sequence alignment editor and analysis program for Windows 95/98/NT. Nucleic Acids Symposium Series 41, 95-98.

Hanlin RT. 1990 - Illustrated Genera of Ascomycetes. APS Press.

Huelsenbeck JP, Ronquist F. 2001 - MRBAYES: Bayesian inference of phylogenetic trees. Bioinformatics 17, 754-755.

Hyde KD, Bussaban B, Paulus B, Crous PW, Lee S, Mckenzie EH, Photita W, Lumyong S. 2007 Diversity of saprobic microfungi. Biodiversity and Conservation 16, 7-35.

Hyde KD, Taylor JE, Fröhlich J. 2000 - Genera of Ascomycetes from Palms. Fungal Diversity Research Series 2, 1-247.

Index Fungorum. 2016 - http://www.indexfungorum.org/Names/Names.asp. Accessed on 2016.

Jayasiri SC, Hyde KD, Ariyawansa HA, Bhat J, Buyck B, Cai L, Dai YC, Abd-Elsalam KA, Ertz D, Hidayat I, Jeewon R, Jones EBG, Bahkali AH, Karunarathna SC, Liu JK, Luangsa-ard JJ, Lumbsch HT, Maharachchikumbura SSN, McKenzie EHC, Jean-Marc Moncalvo, Ghobad-Nejhad M, Nilsson H, Ka-Lai Pang, Pereira OL, Phillips AJL, Raspé O, Rollins AW, Romero AI, Etayo J, Selçuk F, Stephenson SL, Suetrong S, Taylor JE, Tsui CKM, Vizzini A, Abdel-Wahab MA, Wen TC, Boonmee S, Dai DQ, Daranagama DA, Dissanayake AJ, Ekanayaka AH, Fryar SC, Hongsanan S, Jayawardena RS, Li WJ, Perera RH, Phookamsak R, de Silva NI, Thambugala KM, Tian Q, Wijayawardene NN, Zhao RL, Zhao Q, Kang JC, Promputtha I. 2015 - The Faces of Fungi database: fungal names linked with morphology, phylogeny and human impacts. Fungal Diversity 74, 3-18.

Katoh K, Standley K. 2013 - MAFFT Multiple Sequence Alignment Software Version 7: Improvements in Performance and Usability. Molecular Biology \& Evolution 30, 772-780.

Konta S, Phillips AJL, Bahkali AH, Jones EBG, Eungwanichayapant DP, Hyde KD, Boonmee S. 2016 - Botryosphaeriaceae from palms in Thailand-Barriopsis archontophoenicis sp. nov, from Archontophoenix alexandrae. Mycosphere Doi 10.5943/mycosphere/si/1b/1.

Li W, Cowley A, Uludag M, Gur T, McWilliam H, Squizzato S, Park YM, Buso N, Lopez R. 2015 - The EMBL-EBI bioinformatics web and programmatic tools framework. Nucleic acids research, 43, W580-W584.

Ligoxigakis EK, Markakis EA, Papaioannou IA, Typas MA. 2014 - First report of palm rot of Phoenix spp. caused by Neodeightonia phoenicum in Greece. Horticultural Reviews 42, 120.

Liu JK, Chomnunti P, Cai L, Phookamsak R, Chukeatirote R, Jones EBG, Moslem M, Hyde KD. 2010 - Phylogeny and morphology of Neodeightonia palmicola sp. nov. from palms. Sydowia 62, 261-276. 
Liu JK, Phookamsak R, Dai DQ, Tanaka K, Onese BGJ, Xu JC, Chukeatirote E, Hyde KD. 2014 Roussoellaceae, a new pleosporalean family to accommodate the genera Neoroussoella gen. nov., Roussoella and Roussoellopsis. Phytotaxa 181, 1-33.

Liu JK, Phookamsak R, Doilom M, Wikee S, Li YM, Ariyawansha H, Boonmee S, Chomnunti P, Dai DQ, Bhat JD, Romero AI, Zhuang WY, Monkai J, Jones EBG, Chukeatirote E, Ko Ko TW, Zhao YC, Wang Y, Hyde KD. 2012 - Towards a natural classification of Botryosphaeriales. Fungal Diversity 57, 149-210.

Nylander JAA. 2004 - MrModeltest v2.2. Program distributed by the author: 2. Evolutionary Biology Centre, Uppsala University, 1-2.

Page RD. 1996 - TreeView: an application to display phylogenetic trees on personal computers. Computer Applications in the Biosciences 12, 357-358.

Phillips AJL, Alves A, Abdollahzadeh J, Slippers B, Wingfield MJ, Groenewald JZ, Crous PW. 2013 - The Botryosphaeriaceae: genera and species known from culture. Studies in Mycology 76, 51-167.

Phillips AJL, Alves A, Pennycook SR, Johnston PR, Ramaley A, Akulov A Crous PW. 2008 Resolving the phylogenetic and taxonomic status of dark-spored teleomorph genera in the Botryosphaeriaceae. Persoonia 21, 29-55.

Phookamsak R, Norphanphoun C, Tanaka K, Dai DQ, Luo ZL, Liu JK, Su HY, Bhat DJ, Bahkali AH, Mortimer PE, Xu JC. 2015 - Towards a natural classification of Astrosphaeriella-like species; introducing Astrosphaeriellaceae and Pseudoastrosphaeriellaceae fam. nov. and Astrosphaeriellopsis, gen. nov. Fungal Diversity 74, 143-97.

Phukhamsakda C, Ariyawansa HA, Phookamsak R, Chomnunti P, Bulgakov TS, Yang JB, Bhat DJ, Bahkali AH, Hyde KD. 2015 - Muriphaeosphaeria galatellae gen. et sp. nov. in Phaeosphaeriaceae (Pleosporales). Phytotaxa 227, 55-65.

Punithalingam E. 1969 - Studies on Sphaeropsidales in culture. I. Mycological Papers. 119, 1-24.

Rannala B, Yang Z. 1996 - Probability distribution of molecular evolutionary trees: a new method of phylogenetic inference. Journal of Molecular Evolution 43, 304-311.

Silvestro D, Michalak I. 2010 - raxmlGUI: a graphical front-end for RAxML Program. And documentation available from www.sourceforge.com; Accessed August 2010.

Swofford DL. 2002 - PAUP* 4.0: phylogenetic analysis using parsimony (* and other methods). Sinauer Associates, Sunderland.

Tamura K, Stecher G, Peterson D, Filipski A, Kumar S. 2013 - MEGA6: molecular evolutionary genetics analysis version 6.0. Molecular Biology \& Evolution 30, 2725-2729.

Thompson JD, Gibson TJ, Plewniak F, Jeanmougin F, Higgins DG. 1997 - The CLUSTAL_X windows interface: flexible strategies for multiple sequence alignment aided by quality analysis tools. Nucleic Acids Research 25, 4876-4882.

Vilgalys R, Hester M. -1990 Rapid genetic identification and mapping of enzymatically amplified ribosomal DNA from several Cryptococcus species. Journal of bacteriology 172, 42384246.

White T, Bruns T, Lee S, Taylor J. 1990 - Amplification and direct sequencing of fungal ribosomal RNA genes for phylogenetics. In: Innis, M.A., Gelfand, D.H., Sninsky, J.J. \& White, T.J. (Eds.) PCR protocols: a guide to methods and applications. New York, Academic Press 315-322.

Zhaxybayeva O, Gogarten JP. 2002 - Bootstrap, Bayesian probability and maximum likelihood mapping: exploring new tools for comparative genome analyses. BMC Genomics 3, 4. 